\title{
THE RESULTS OF VALVOTOMY FOR SIMPLE PULMONARY STENOSIS
}

\author{
BY \\ MAURICE CAMPBELL AND SIR RUSSELL BROCK \\ From Guy's Hospital
}

Received November 3, 1954

The medical aspects of simple pulmonary stenosis, i.e. valvular stenosis with a closed ventricular septum, have been discussed recently (Campbell, 1954). We wish now to describe the results after pulmonary valvotomy, as we have those after anastomotic and direct operation in Fallot's tetralogy (Campbell and Deuchar, 1953: Campbell, Deuchar, and Brock, 1954). We have carried out the follow-up in the same way, but some important differences need emphasis.

In Fallot's tetralogy the disability of the patient is always the reason for operation, and improvement is judged mainly by the increased capacity and lessened cyanosis. A smaller heart or less right ventricular preponderance can not be expected, since the right ventricle is still working against a pressure that is the same, or nearly the same, as the systemic pressure. In fact, if the result is good clinically, success is judged by an absence of too much increase in the size of the heart or of right ventricular strain in the electrocardiogram, for after four or five years some patients are showing this latter change. Fortunately, so far, this is not reflected in any loss of ground clinically, but taking a longer view, it probably will be and this means that the great improvement obtained after these operations may generally be limited to perhaps ten or twenty years.

In simple pulmonary stenosis there are several differences. Many patients have enough disability to make this the main reason for operation, and the result can be judged in the same way by the improvement in their capacity and cyanosis, if this was present. Others, however, have little disability and operation is advised because of the high pressure in the right ventricle and the cardiographic signs of increasing right ventricular strain. We have, therefore, assessed the improvement of some patients by their increased capacity as well as by objective methods and of others only by the latter because they could do so much before; though many who said they had little disability before operation found, in fact, that they could do more and do it more easily afterwards.

Because of this the results are sometimes less dramatic to these patients than to those with Fallot's tetralogy, but from the longer point of view the operation is a better one as it comes nearer to the ideal of making the heart normal. After a successful operation, there is often the satisfaction of seeing a large heart become smaller (Fig. 1) and no reason to expect that it will ever become larger: generally there is a diminution or even a disappearance of right ventricular strain (Fig. 2) instead of an increase as there may be after operation in Fallot's tetralogy. If the valve does not narrow again from fibrosis or other changes, the improvement should last indefinitely. Some patients have, however, reached such a late stage with a large heart and gross right ventricular strain that operation can hardly be expected to restore them to normal, though it should improve them.

Further, cardiac catheterization plays a more important part in the assessment of the results, because the pressure in the right ventricle is often a main reason for the operation. We think, however, on the evidence to be presented that improvement in the electrocardiogram makes it certain that the right ventricular pressure has been reduced, even without catheterization.

Four years ago we reported the results after valvotomy in 17 cases of simple pulmonary stenosis 229 


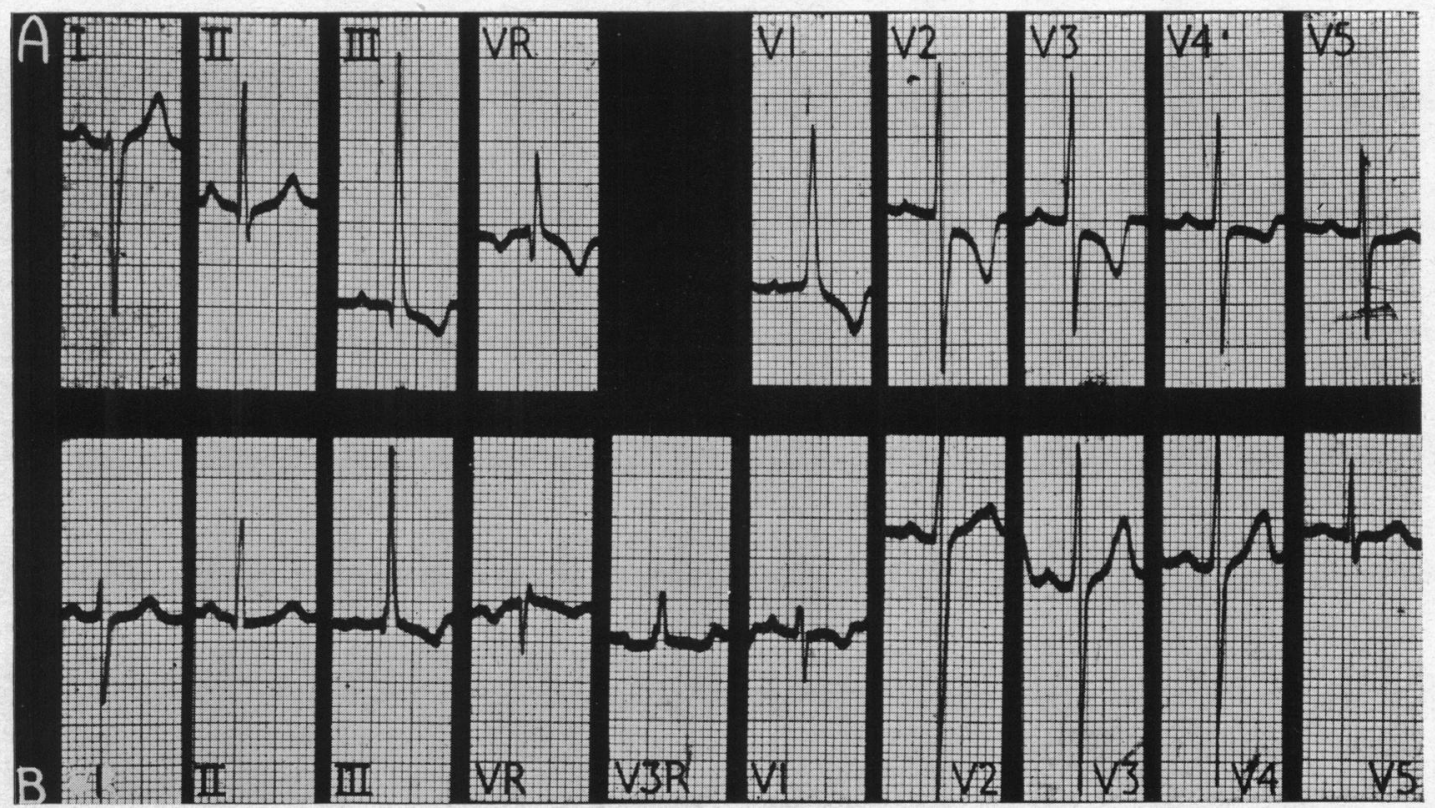

FIG. 2.-Disappearance of right ventricular strain and even of preponderance after valvotomy for simple pulmonary stenosis with cyanosis. (A) Before operation, showing $T$ inversion to V4. (B) Three years after, showing $T$ inverted in III and V1 only, and much less right ventricular preponderance. Case V47 (P208). 
and showed that the right ventricular pressure could be reduced to half of its previous level (Case 30, Brock and Campbell, 1950). Now the number who have been submitted to operation has risen to 92, but this detailed follow-up is concerned with the 58 patients who have been operated on at Guy's Hospital: similar results have been obtained in the other 34 patients. We have divided them according to the presence or absence of central cyanosis when they were out-patients, and 25 were cyanotic and 33 were acyanotic.

Most of those who were acyanotic had an arterial oxygen saturation of 95 per cent or above, but it was between 92 and 94 per cent in four, in whom we thought there was no central cyanosis at rest. In three of these and in four others-nearly one-quarter of the whole-there were good reasons for thinking that they sometimes had a right-to-left shunt with exercise, and several others complained of some degree of peripheral cyanosis especially when it was cold.

The degree of arterial anoxæmia was very variable in those who had central cyanosis at rest. In seven it was under 70 per cent, in four under 80 per cent, and in three under 85 per cent. This means that more than half were below this level but nearly half had only a small shunt with an arterial oxygen saturation above this. In six it was between 85 and 89 per cent, two of these looking more cyanotic than this would suggest; in two it was 90 per cent, in two it was 91 per cent, and the cyanosis which seemed much more severe must have been mainly peripheral; and in the last, who became much more cyanosed during her paroxysms of tachycardia, it was 92 per cent.

\section{SeX AND Age INCIDENCE}

Simple pulmonary stenosis has no special predeliction for either sex. This was also true of the 58 patients who had operations ( 27 male, 31 female) though, probably by chance, there were rather more women among the cyanotic cases.

The patients were older than those with Fallot's tetralogy and one-third were over 20 years of age (Table I). Most were between 5 and 29 years, but three cyanotic children needed operation when they were only 4 years old, and five patients were over 30 , the eldest being 42 years.

TABLE I

Sex and Age Incidence of Patients having Valvotomy for Simple Pulmonary Stenosis

\begin{tabular}{|c|c|c|c|c|c|c|c|c|c|c|c|}
\hline \multicolumn{3}{|c|}{ Age in years } & $0-4$ & $5-9$ & $10-14$ & $15-19$ & $20-24$ & $25-29$ & $30-39$ & $\begin{array}{l}40 \\
\text { and }\end{array}$ & Total \\
\hline $\begin{array}{l}\text { Acyanotic . } \\
\text { Cyanotic : }\end{array}$ & $\begin{array}{l}. . \\
. .\end{array}$ & $\begin{array}{l}. \\
. .\end{array}$ & $\begin{array}{l}0 \\
3\end{array}$ & $\begin{array}{l}5 \\
6\end{array}$ & $\begin{array}{r}10 \\
3\end{array}$ & $\begin{array}{l}7 \\
4\end{array}$ & $\begin{array}{l}4 \\
3\end{array}$ & $\begin{array}{l}4 \\
4\end{array}$ & $\begin{array}{l}2 \\
2\end{array}$ & $\begin{array}{l}1 \\
0\end{array}$ & $\begin{array}{l}33 \\
25\end{array}$ \\
\hline $\begin{array}{l}\text { Male } \\
\text { Female }\end{array}$ & 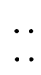 & 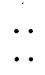 & $\begin{array}{l}2 \\
1\end{array}$ & $\begin{array}{l}4 \\
7\end{array}$ & $\begin{array}{l}8 \\
5\end{array}$ & $\begin{array}{l}6 \\
5\end{array}$ & $\begin{array}{l}4 \\
3\end{array}$ & $\begin{array}{l}1 \\
7\end{array}$ & $\begin{array}{l}2 \\
2\end{array}$ & $\begin{array}{l}0 \\
1\end{array}$ & $\begin{array}{l}27 \\
31\end{array}$ \\
\hline Total & . & .. & 3 & 11 & 13 & 11 & 7 & 8 & 4 & 1 & 58 \\
\hline
\end{tabular}

At first sight it is surprising that the age incidence of these patients who have had an operation is much the same as that of all those we have seen. If our selection of patients for operation is reasonable this means that there is no special age at which symptoms or other indications, such as the right ventricular pressure, become progressively important, and that this may happen at any time though not very often after 24 in men or after 29 in women.

The sex did not appear to influence the age incidence greatly except that ten of the thirteen patients over 25 were women.

\section{OPERATIVE MORTALITY}

Pulmonary valvotomy for simple pulmonary stenosis is not a dangerous operation if the patient is not left till too late. The first acyanotic patient, a girl, aged 9 , who had congestive failure and a 
huge heart died during the operation, but 32 acyanotic patients have been operated on since without a death.

The early cyanotic patients had reached an advanced stage of their disease and four of the first five died, but since then there have been only three deaths among twenty cases. Two of these three were gravely ill; one was a man, aged 33, who had got on well until some years before, but had auricular fibrillation, a very large heart, and congestive failure with recurrent ascites, so that he had been almost bedridden for the last year. The second was a girl, aged 19, who had obtained no lasting benefit from a subclavian-pulmonary anastomosis in America some years before, and had developed deep cyanosis and congestive failure. The third, a girl, aged 25 , had increasingly frequent paroxysms of ventricular tachycardia which proved impossible to control after her operation. Thus, since the end of 1949, excluding the two with heart failure, only one patient has died, and if we had allowed more time to bring her paroxysms under better control before operation, the fatal result might have been avoided.

The total operative mortality was 14 per cent, but 5 of the deaths were in the first 6 operations and since then it has been less than 6 per cent: even these later cases included many who were gravely disabled and nearly all had a right ventricular systolic pressure over $100 \mathrm{~mm}$. $\mathrm{Hg}$, often with severe signs of right ventricular strain.

\section{The Results after Pulmonary Valvotomy}

The results had been good in 46 of the 50 patients who survived operation. Among the 33 acyanotic patients only one has died, leaving 32 to be followed. Among the 25 cyanotic patients, seven have died, leaving 18 to be followed. Of the 50 survivors, 11 have been followed for from four to six years, 10 for three years, 13 for two years, 13 for one year, and 3 for some months only. None has been lost sight of, but we have accepted reports from their doctors for two patients overseas whom it has not been possible to examine. All the others have been seen regularly. The results are shown in Table II. Several individual cases were reported in detail in our earlier paper so this has not been thought necessary here, but the subsequent history of Case 7 is given shortly.

TABLE II

Results of Valvotomy in Simple Pulmonary Stenosis

\begin{tabular}{|c|c|c|c|c|}
\hline & $\begin{array}{l}\text { No. of } \\
\text { cases }\end{array}$ & Deaths & $\begin{array}{l}\text { Good } \\
\text { results }\end{array}$ & $\begin{array}{l}\text { Poor } \\
\text { results }\end{array}$ \\
\hline \multirow{2}{*}{$\begin{array}{l}\text { P.V.S. pure (acyanotic) } \\
\text { P.V.S. with P.F.O. } \\
\text { (cyanotic) } \quad \text {.. }\end{array}$} & 33 & $1^{*}$ & $28 \ddagger$ & $4 \ddagger$ \\
\hline & 25 & $7 \dagger$ & $18 \ddagger$ & 0 \\
\hline
\end{tabular}

A woman, aged 26, was deeply cyanosed and could walk no more than 100 yards; she was losing ground rapidly. Eleven months after operation she was leading a normal life and gave birth to a child with no special difficulty. After six years she is leading an active life as a housewife and can walk several miles and do all the work she wants.

Cyanotic Group. Here it is easy to judge the results because all the patients were greatly improved in their capacity and in their colour and all but one had symptoms that by themselves were severe enough to indicate operation.

This clinical improvement was confirmed by the heart becoming smaller in 10 patients (Fig. 1 and 3) including all but one of those where it was much enlarged. In 11 of the 12 with evidence of right ventricular strain before operation, this became less and in 5 the change was specially striking (Fig. 2 and 6). The right ventricular pressure was greatly reduced in all the nine who have had 


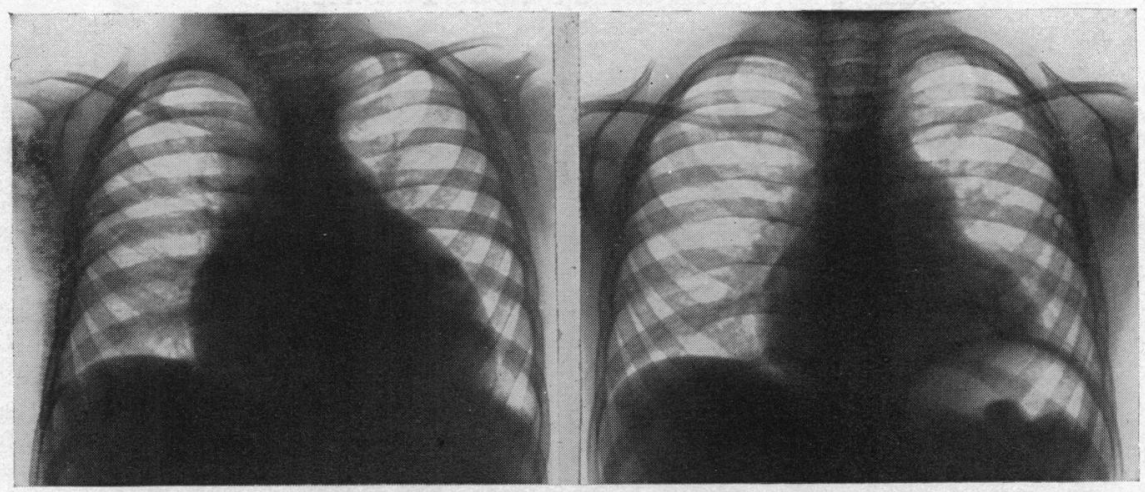

A

B

Fig. 3.-Great reduction in heart size after pulmonary valvotomy in a child who developed severe symptoms and cyanosis early. (A) Before operation, c.t.r. 68 per cent (m.t.d. $11 \cdot 3 / 16 \cdot 8 \mathrm{~cm}$.). (B) One year after, c.t.r. 59 per cent (m.t.d. 10:1/17.1 cm.). Case V94 (O897).

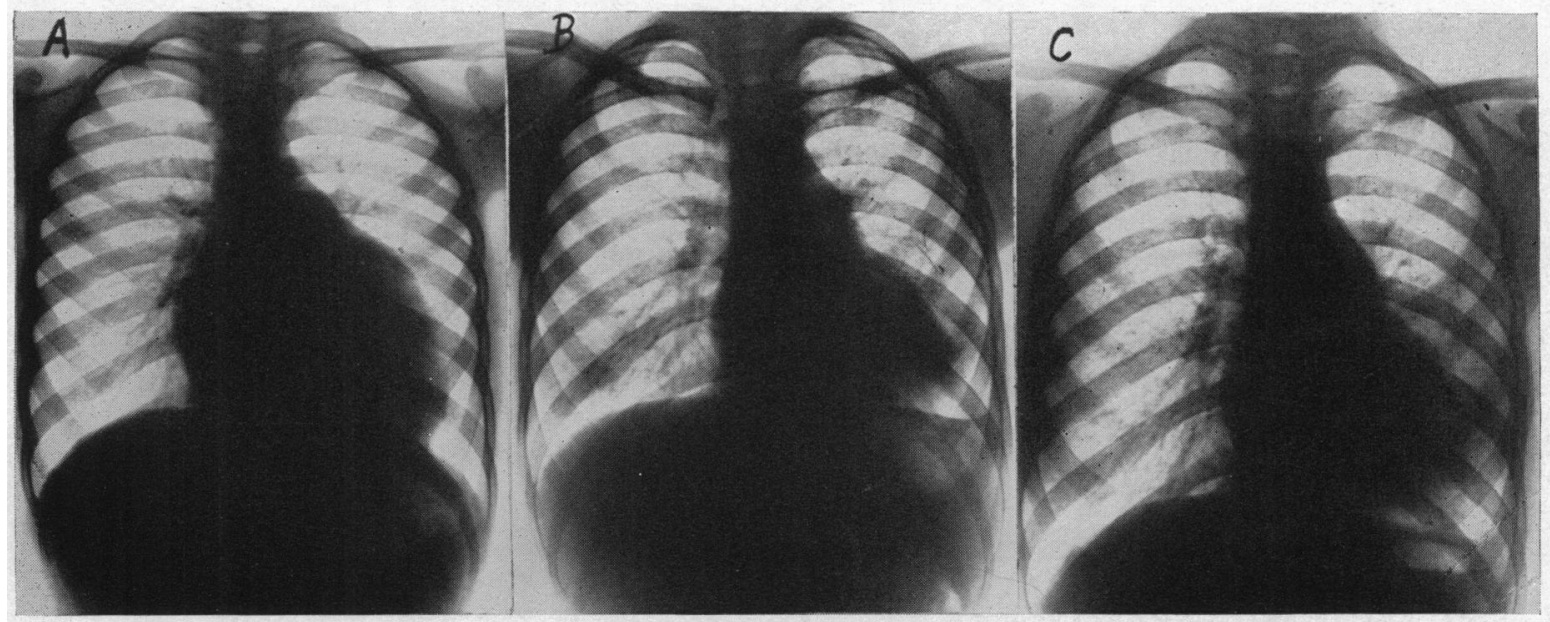

FIG. 4.-Great reduction in heart size after valvotomy for acyanotic pulmonary stenosis. (A) Before operation, showing great enlargement (c.t.r. $63 \%$ : m.t.d. $12 \cdot 6 / 19 \cdot 8 \mathrm{~cm}$.) and the characteristic humped left border due to hypertrophy of the right ventricle. (B) Much diminution in size eighteen months after operation (c.t.r. $54 \%:$ m.t.d. $11 \cdot 8 / 22 \mathrm{~cm}$.). The pulmonary arteries seem larger and the pulmonary blood flow more normal. (C) Three years after operation she had grown a lot and indulged in an active life, but the increase in the chest is greater than in the heart (c.t.r. 53\%: m.t.d. $12 \cdot 2 / 23 \mathrm{~cm}$.). Case V39 (0468).

catheterization after operation, nearly always to less than half of what it had been before and on an average from 127 to $44 \mathrm{~mm}$. (Table VII).

Acyanotic Group. Here it is sometimes more difficult to judge the improvement on clinical grounds, because many patients had few symptoms and were operated on because of the high right ventricular pressure and right ventricular strain. Sixteen of the 32 patients, however, had severe symptoms and all but one of these were greatly improved: unfortunately one has been unable to take much advantage of this as he has developed pulmonary tuberculosis. The symptoms were much improved in 8 others but they had not been severe enough by themselves to justify operation. There were 5 others where they were so slight that they were little guide to the result: for example, 
one man who had been leading a normal life could cycle up a particular hill on the way to work more easily than before, but such a change is not really reliable.

The results were disappointing in four patients only, all of whom were acyanotic. One woman, aged 25 , seemed better at first and resumed the work that she had had to give up two years before, but a year later she found it difficult and seemed no better than before, although the pressure had been reduced from 112 to $55 \mathrm{~mm}$. $\mathrm{Hg}$ (Case V80). The second, a boy aged 14, had few symptoms before operation in spite of his high right ventricular pressure; he developed bundle branch block during the operation and it has persisted; he cannot do so much as before and the heart is larger (Case V104). The third, a man, aged 33, has not obtained great benefit though the right ventricular pressure has been reduced from 190 to $107 \mathrm{~mm}$. (Case V108). The fourth, a girl, aged 10, was operated on six months ago and does not seem much better and her heart has become larger: there is some pulmonary regurgitation but it hardly seems enough to account for her condition (Case V121).

The clinical improvement was confirmed in 7 patients by a diminution of heart size, which was sometimes very striking (see Fig. 4 and 10), and in most others there was little or no enlargement before operation and no change was expected or found. Further confirmation was obtained by diminution of right ventricular strain in 16 patients (Fig. 7-9), though sometimes this was less than was hoped for judged by the good results in other ways. In all the 15 patients who had been recatheterized the result has been good and the right ventricular pressure has been reduced, generally to between one-half and one-third of the previous level (Table VIII).

Pulmonary Regurgitation. When pulmonary valvotomy was under consideration, the possible production of pulmonary regurgitation was one of the things that was feared. When we reported the early results we had not seen this happen (Brock and Campbell, 1950), but since then it has occurred in three of these patients and must be remembered as one of the risks to be considered in advising operation.

In one (Case V69) who was able to do more and felt better, the cardiothoracic ratio increased from 53 to 57 but is now back to 55 per cent; even this is disappointing because an increase from 47 to 53 in the two years before operation was one of the main reasons for advising it. The second (Case V75) has also improved and the heart has become rather smaller, so probably the regurgitation is slight. The third (V121), a recent case, has shown a disappointing result and the degree of pulmonary regurgitation hardly seems an adequate reason for this.

\section{Cyanosis and Polycythaemia}

Many of the early patients had severe cyanosis and an arterial $\mathrm{O}_{2}$ saturation between 60 and 80 per cent. The heavy mortality at this stage showed that the operation should have been due earlier and made us think that the onset of cyanosis might be an urgent indication: this is true for progressive or severe cyanosis but is not always so for the slighter degrees of cyanosis.

The cyanosis can be abolished much more easily than with Fallot's tetralogy. When the arterial $\mathrm{O}_{2}$ saturation was above 70 per cent., it has always become normal and all cyanosis has disappeared. Where it was below this, it has always become much better, rising to a figure above 85 per cent, and generally to normal even in this group (see Table VII).

Cyanotic cases develop polycythæmia and an increased hæmoglobin percentage in the same way as those with Fallot's tetralogy, though the average increase is rather less. With the improvement of the cyanosis after operation the polycythæmia and hæmoglobin percentages return towards normal, even more decisively than in Fallot's tetralogy after a successful operation. In the 17 patients where the results are available one to six years after operation, the hæmoglobin fell from an average of 120 to 88 per cent, and its range before and after pulmonary valvotomy is shown in Table III.

\section{The Size of the Heart after Operation}

With Fallot's tetralogy a successful operation, whether anastomotic or direct, tends to be followed by some increase in the size of the heart and the best thing that can be hoped for is that there 
TABLE III

The Fall in the Haemoglobin Percentage after Valvotomy in Simple PUlmonARY Stenosis

\begin{tabular}{|c|c|c|c|c|c|c|c|c|}
\hline & & \multicolumn{7}{|c|}{ Hæmoglobin percentage } \\
\hline & & $80-89$ & $90-99$ & $100-109$ & $110-119$ & $120-129$ & $130-139$ & $140-159$ \\
\hline $\begin{array}{l}\text { Before valvotomy } \\
\text { After valvotomy }\end{array}$ & $\begin{array}{l}\cdots \\
\cdots\end{array}$ & $\overline{10}$ & $\begin{array}{l}4 \\
5\end{array}$ & $\begin{array}{l}2 \\
2\end{array}$ & $\underline{2}$ & $\frac{4}{-}$ & $\underline{3}$ & $\frac{2}{-}$ \\
\hline
\end{tabular}

is no further increase. With simple pulmonary stenosis, however, the position is quite different and a large heart may be expected to become smaller (Fig. 1, 3, 4, and 10). There are 19 cases where figures are available and the patient has been followed for three years. In the 9 with a larger heart (c.t.r. $54 \%$ or over) the decrease was 10 per cent, most but not all of this change being seen in the first year. The average cardiothoracic ratio was 60 and after a year it had fallen to $55 \cdot 8$, and after three years to 53.8 per cent (Table IV). Individual results of all those with a large heart are shown in Table V, where it will be seen that Case V40 was alone in showing no reduction in size, though sometimes, e.g. Case V45, the reduction was less than one hoped for. In the 10 with a smaller heart (c.t.r. $53 \%$ or less) the average figure was 47.6 per cent, and three years later it was just the same. Some of these decreased a little but some of the very small hearts became larger with increasing activity (Fig. 5). The cyanotic and acyanotic cases were analysed separately but, in fact, the behaviour of the heart as regards its size was the same in the two groups so they have been combined.

TABLE IV

Reduction in Heart Size after Valvotomy in Simple Pulmonary Stenosis

\begin{tabular}{ll|c|c|c|c|c}
\hline & & \multicolumn{4}{|c}{ Cardiothoracic ratio } \\
\cline { 4 - 7 } & & $\begin{array}{c}\text { Before } \\
\text { operation }\end{array}$ & $\begin{array}{c}\text { After } \\
1 \text { year }\end{array}$ & $\begin{array}{c}\text { After } \\
2 \text { years }\end{array}$ & $\begin{array}{c}\text { After } \\
3 \text { years }\end{array}$ \\
\hline C.t.r. $54 \%$ and over (9 cases) & $\ldots$ & $\ldots$ & $60 \cdot 0$ & $55 \cdot 8$ & $54 \cdot 1$ & $53 \cdot 8$ \\
C.t.r. $53 \%$ and less (10 cases) & $\ldots$ & $\ldots$ & $47 \cdot 6$ & $48 \cdot 5$ & $48 \cdot 1$ & $47 \cdot 6$ \\
\hline
\end{tabular}

In the cyanotic group the heart became much smaller in 7 patients (Fig. 1, 4, and Table V), including all the five where the cardiothoracic ratio was over 60 per cent, and smaller in 3 others and there was only one (V40) where a large heart did not become smaller; there was no obvious reason as the result was very good in other ways. In the acyanotic group it became smaller, sometimes very much so, in 7 patients (Fig. 3 and Table V) and in another 22 there was little or no enlargement before operation and no change was expected or found.

Only three patients were disappointing in this respect. One has been mentioned in the section on pulmonary regurgitation (Case V69). The other two were among the four with poor clinical results and the heart became larger, c.t.r. 51 to 58 per cent after one year in Case V104 and from 59 to 62 per cent after six months in Case V121.

\section{Electrocardiographic Changes After Operation}

The pattern of $T$ inversion spreading across the chest leads to V4 or further is common in severe cases of simple pulmonary stenosis and is one of the strong indications for pulmonary valvotomy. It is, therefore, of interest to see how far this pattern can be reversed after a successful valvotomy, 


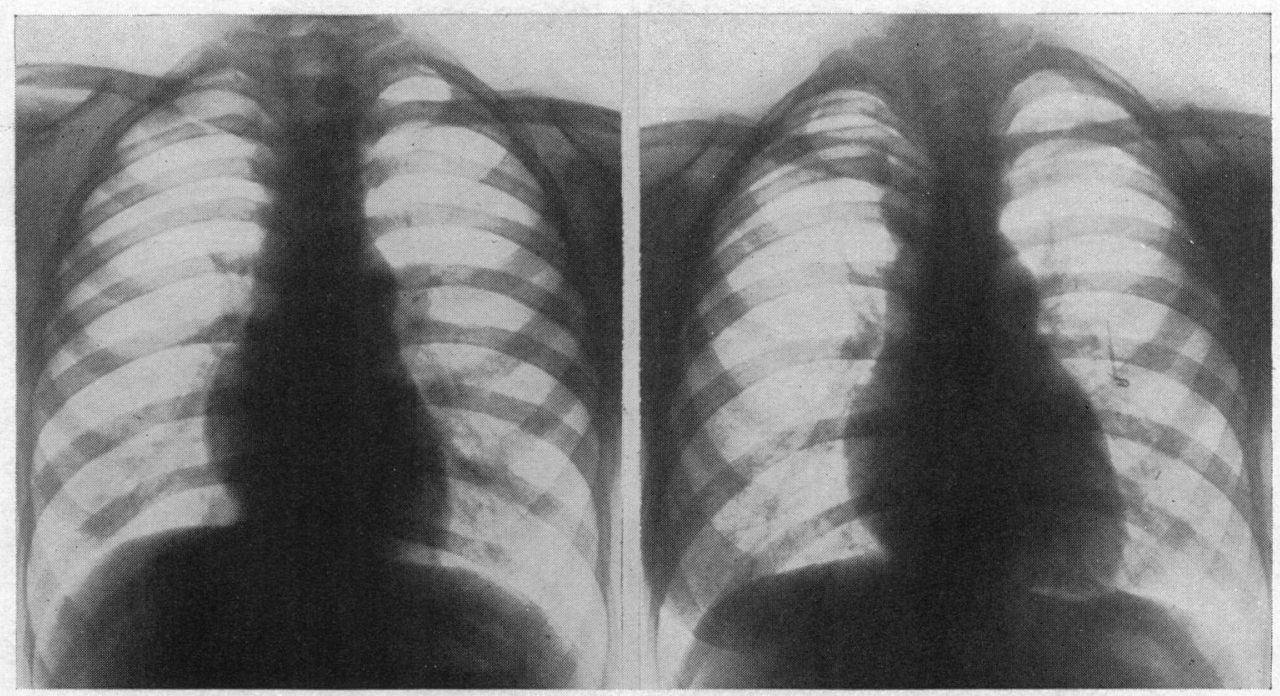

A B

FIG. 5.-A small heart increasing to normal size with increasing activity after valvotomy. (A) Before operation, c.t.r. 44 per cent (m.t.d. $10 \cdot 0 / 22 \cdot 5 \mathrm{~cm}$.). (B) A year after, when she was leading a very active life, c.t.r. 48 per cent. (m.t.d. $11 \cdot 9 / 25 \mathrm{~cm}$.). Case V89(O715).

TABLE V

Reduction of Cardiothoracic Ratio after Valvotomy in Simple Pulmonary Stenosis

\begin{tabular}{|c|c|c|c|c|c|c|}
\hline \multirow{2}{*}{ Case No. } & \multirow{2}{*}{$\begin{array}{l}\text { Age } \\
\text { and } \\
\text { sex }\end{array}$} & \multirow{2}{*}{$\begin{array}{l}\text { Before } \\
\text { operation }\end{array}$} & \multicolumn{4}{|c|}{ After operation } \\
\hline & & & 1 year & 2 years & 3 years & 4 years \\
\hline \multicolumn{7}{|c|}{ Acyanotic } \\
\hline V39 & $9 \mathrm{~F}$ & 63 & 56 & 54 & 53 & 52 \\
\hline V45 & $29 \mathrm{~F}$ & 68 & 63 & 61 & 63 & 62 \\
\hline V46 & $8 \mathrm{M}$ & 56 & 52 & 52 & 53 & 54 \\
\hline V75 & $6 \mathrm{~F}$ & 63 & 58 & 58 & - & - \\
\hline V88 & $11 \mathrm{M}$ & 55 & 53 & 53 & - & - \\
\hline V93 & $42 \mathrm{~F}$ & 60 & 57 & & - & - \\
\hline V97 & $33 \mathrm{~F}$ & 69 & 55 & & - & - \\
\hline \multicolumn{7}{|c|}{ Cyanotic } \\
\hline V40 & $5 \mathrm{~F}$ & 56 & 56 & 56 & 56 & 56 \\
\hline V41 & $11 \mathrm{M}$ & 59 & 51 & 50 & 49 & 48 \\
\hline V49 & $8 \mathrm{M}$ & 56 & 53 & 53 & 53 & - \\
\hline V71 & $26 \mathrm{~F}$ & 54 & 52 & 52 & 49 & - \\
\hline V73 & $19 \mathrm{~F}$ & 64 & 59 & 57 & 56 & - \\
\hline V74 & $5 \mathrm{M}$ & 64 & 60 & 52 & 52 & - \\
\hline V84 & $4 \mathrm{M}$ & 66 & $\begin{array}{l}64 \\
59\end{array}$ & 60 & 二 & - \\
\hline $\begin{array}{l}\text { V94 } \\
\text { V114 }\end{array}$ & $\begin{array}{l}3 \mathrm{M} \\
4 \mathrm{~F}\end{array}$ & $\begin{array}{l}68 \\
65\end{array}$ & $\begin{array}{l}59 \\
54\end{array}$ & - & - & $\overline{-}$ \\
\hline
\end{tabular}


and the result is very encouraging. In 26 of the 31 with this pattern there was some improvement and in half of them it was very striking (Table VI, Fig. 2 and 6-9).

It is difficult to judge how soon this improvement starts because these patients, like others who have section of the right ventricle, show after operation (Fig. 6B) an increase in T inversion that only passes off gradually in the course of three to four months. But we are disappointed if there is no improvement after six months though it may be progressive sometimes for two or even three years: we hardly expect improvement unless it has started within a year.

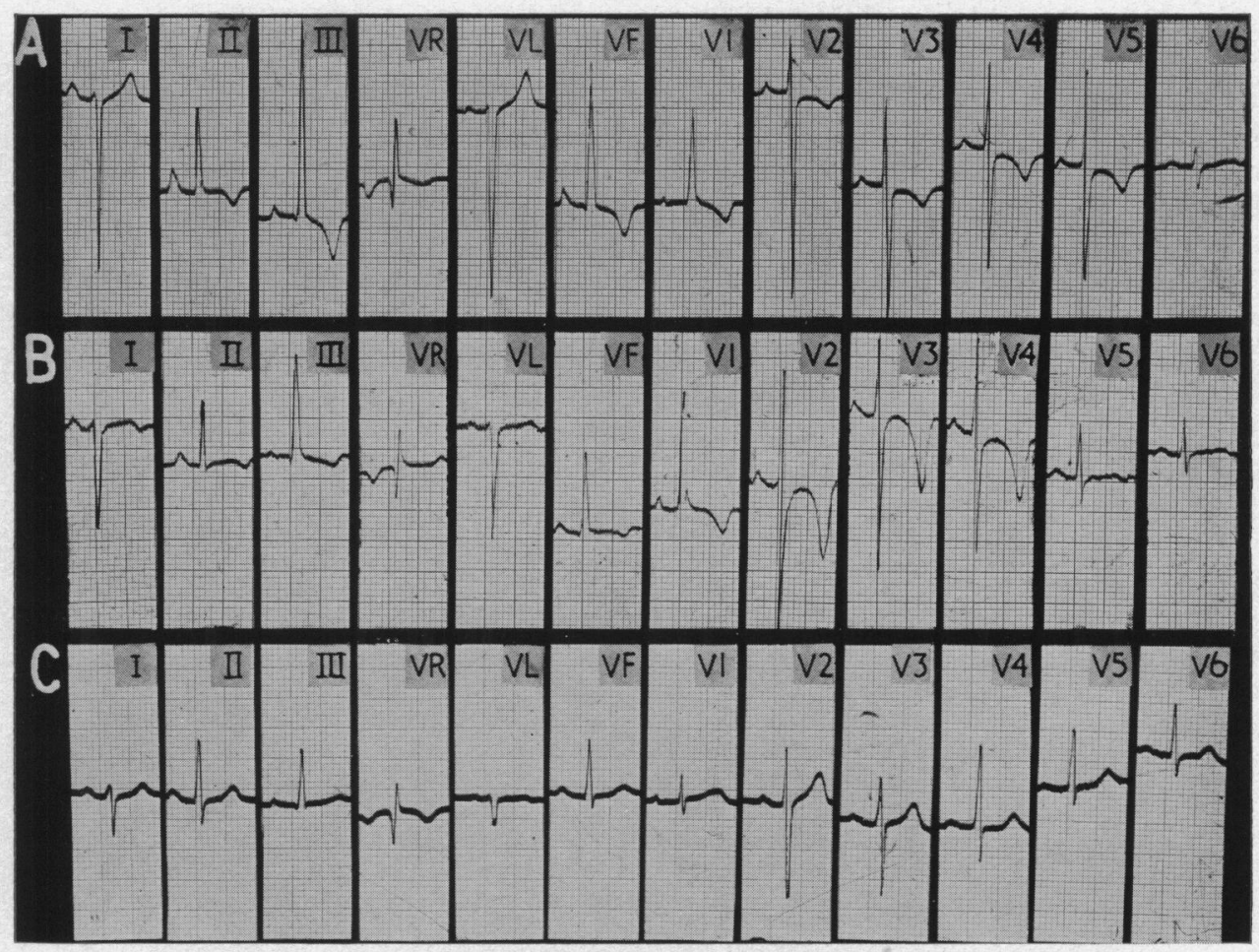

Fig. 6.-Disappearance of right ventricular strain and diminution of right preponderance from a girl, aged 7, with pulmonary stenosis and central cyanosis. (A) Before operation. (B) Three weeks after, showing much deeper $T$ wave inversion in leads I, V2, V3, and V4. (C) Four years after, showing disappearance of all $\mathrm{T}$ wave inversion and much less right ventricular preponderance. Case V23 (H115).

TABLE VI

Diminution or Right Ventricular Strain after Valvotomy in Simple Pulmonary Stenosis

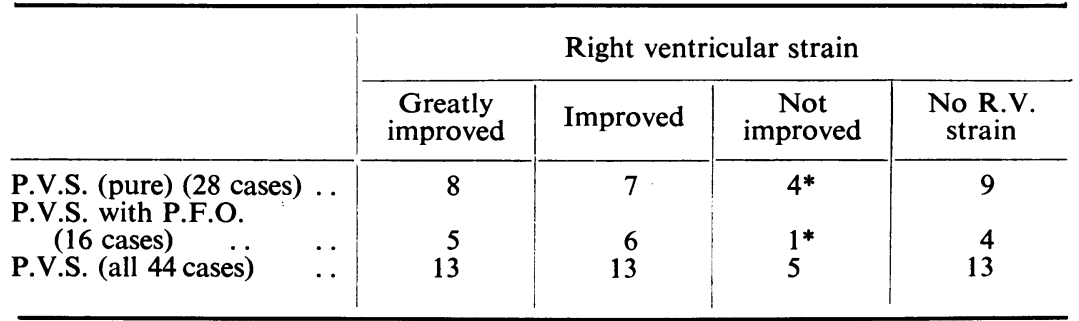

* One in each of these groups had a very good result clinically. 
The cyanotic and acyanotic patients were analysed separately but as there seemed to be no difference the results have been combined. Of the 44 patients with records over a long enough time, 13 showed no right ventricular strain before operation, leaving 31 for consideration. Thirteen of these showed striking changes, the deep $\mathrm{T}$ inversion having disappeared or moved from V4 to V1 or from V5 to V2 or more (see Fig. 6-9); the result was exceptionally good in two where in addition to the disappearance of the $\mathrm{T}$ inversion, there was an unusual decrease in the right ventricular preponderance (see Fig. 2 and 6). All these have obtained excellent results clinically. Eight others improved but less than this, the $T$ inversion having shifted one or two leads further to the right only or having become biphasic or late-rising instead of inverted (Fig. 8 and Fig. 8 of Campbell, 1954). One of these was disappointing at first in that her clinical result was excellent but the $T$ inversion had only spread back from V4 to V3 after three years; after four years, however, there was further improvement and $\mathrm{T}$ was only biphasic in V2 and late rising in V3 (Case V39).

In three patients, however, the change was less than hoped for, the $T$ inversion disappearing from V4 but still being present as far as V3. One of these has a good clinical result and has been followed for a year only but it may be her age of 40 years that prevents more change (Case V93). One is a good result clinically and her very large heart (c.t.r. 69) has become smaller, but she was 29 and it may be that the operation was too late or not complete enough to get a reversal of the right ventricular strain (Case V45). In the third, operation was advised only because of his high right ventricular pressure and right ventricular strain: the former has fallen from 110 to 55 and it is, therefore, disappointing that after two years he has shown no more cardiographic change (Case V92). Two others were difficult to assess, as they had complete right bundle branch block but the $T$ inversion does not now spread so far across the chest leads.

There were only 5 cases where there was little or no improvement and two of these were among those with poor results clinically. In one with a good result (Case V49) $\mathrm{T}$ was inverted to V4 before operation and still is, though rather less so, and the slightly biphasic T in V5 and V6 has disappeared. The second achieved a good result clinically and there had been $T$ inversion across to V6: perhaps

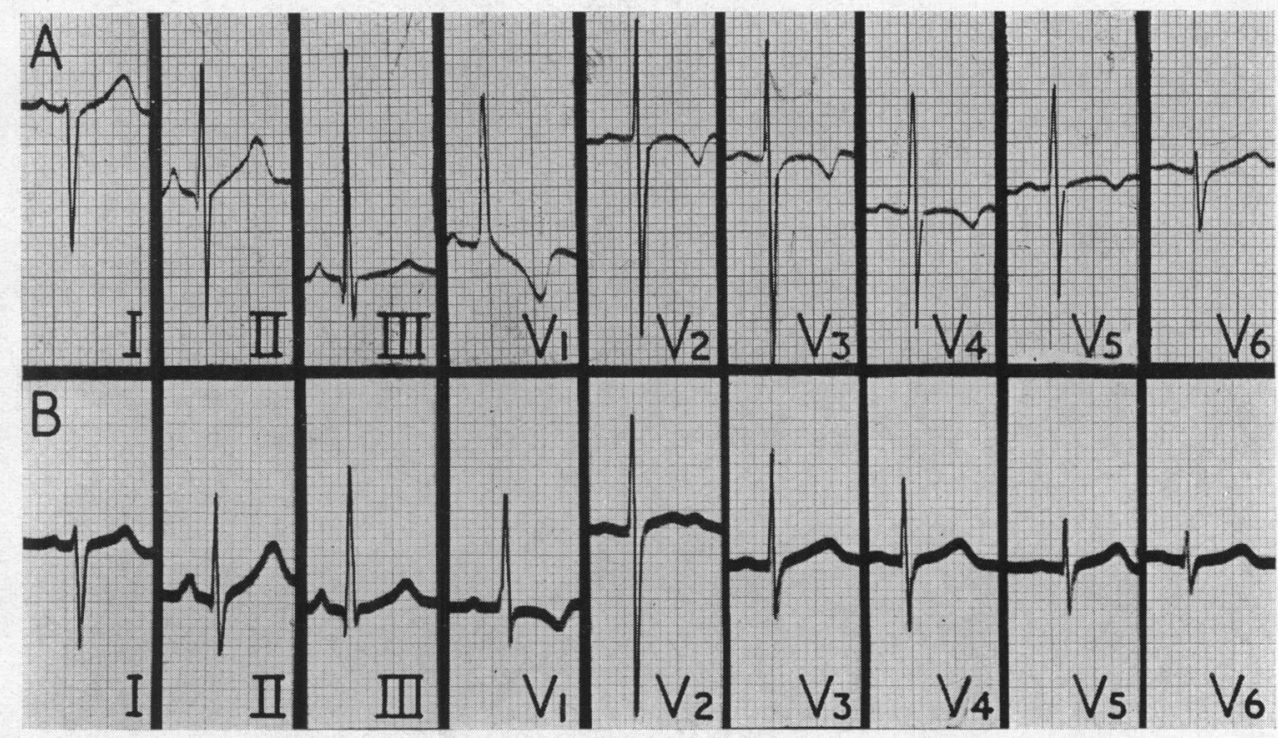

FIG. 7.-Considerable improvement in $T$ inversion three years after valvotomy for acyanotic pulmonary stenosis. (A) Before operation, T sharply inverted from V1 to V4 and slightly in V5. (B) Three years after, $\mathrm{T}$ is less inverted in V1 and upright in all other chest leads, though notched in V2. The $Q / R$ ratio in VR was 1 instead of $1 / 4$. The standardization in the chest leads is $1 \mathrm{mV}=0.5 \mathrm{~cm}$. Case V30 (P247). 


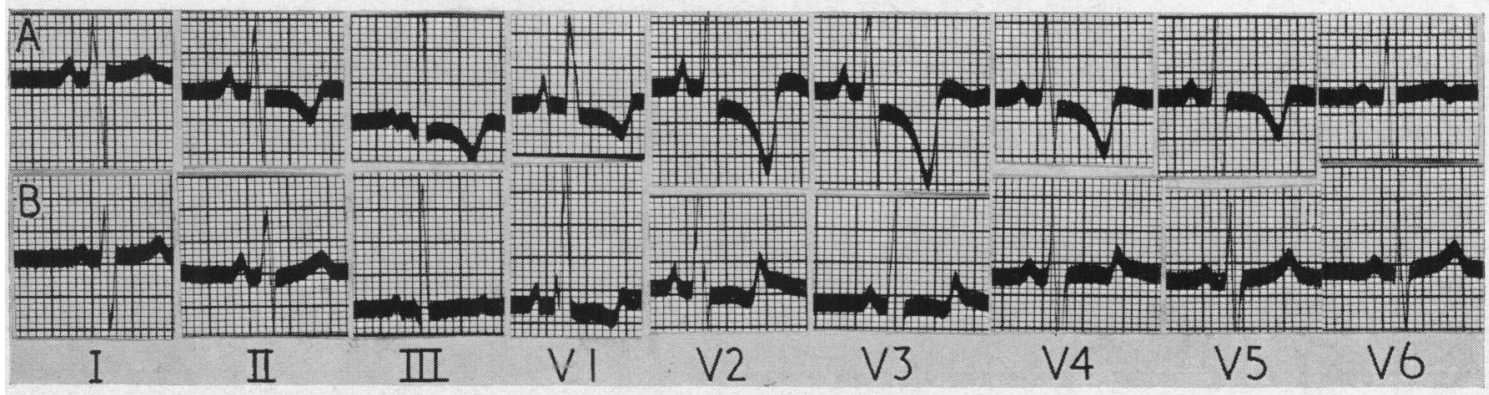

FIG. 8.-Great diminution of right ventricular strain after valvotomy for acyanotic pulmonary stenosis. (A) Before operation, with deep T inversion in leads II and III and from V1 to V5. (B) One year after operation, no longer showing the $T$ waves inverted though they are still late rising (wing-shaped) in V1-V4. Case V88 (H356).

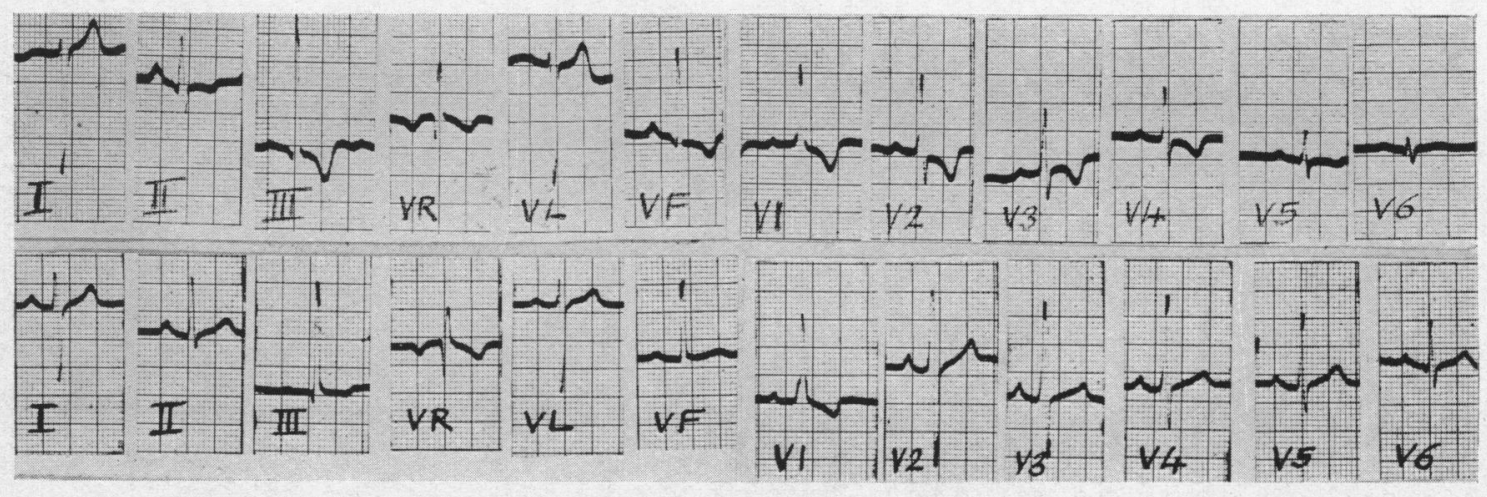

FIG. 9.-Disappearance of the pattern of right ventricular strain after valvotomy for acyanotic pulmonary stenosis. (A) Standard and chest leads before operation. (B) One year after operation. The improvement is even greater than appears, for the standardization of the chest leads in (A) is $1 \mathrm{mV}=0.5 \mathrm{~cm}$. Case V58 (P274).

because she was 25 years old, or perhaps because she has so far been followed only for a year there has been no improvement (Case V105). One patient with pulmonary regurgitation already referred to showed no change, $T$ remaining inverted to V3. The last two were poor results clinically: in one a slight increase of right ventricular strain, $\mathrm{T}$ becoming inverted to $\mathrm{V} 2$, confirmed the clinical judgment (Case V80) and in the other (V104) bundle branch block developed during operation and persisted.

\section{Right Ventricular Pressure}

Pulmonary valvotomy is very effective in reducing the systolic pressure in the right ventricle: in all the 24 patients when catheterization was repeated after operation it was reduced to less than half of its previous level. The average pressure gradient fell to a third, from 122 to $42 \mathrm{~mm}$.

In the 9 cyanotic cases the average change was a fall from $151 / 6$ to $50 / 4 \mathrm{~mm}$. with a pressure gradient of $32 \mathrm{~mm}$. This reduction took place with little change in the pulmonary arterial pressure which rose only from $14 / 6$ to $18 / 7 \mathrm{~mm}$. Two (Cases V23 and V78) showed a fall to normal and most systolic pressures fell to between 45 and $60 \mathrm{~mm}$. (Table VII).

Equally important, the right-to-left shunt was reduced and generally abolished, but in two (Cases V7 and V59) a much smaller shunt persisted. On the average, the $\mathrm{O}_{2}$ saturation in the 
TABLE VII

Physiological Data in Cyanotic Pulmonary Valve Stenosis Before and After Valvotomy

\begin{tabular}{|c|c|c|c|c|c|c|c|c|c|c|c|c|}
\hline \multirow{3}{*}{$\begin{array}{l}\text { Case } \\
\text { No. }\end{array}$} & \multirow{3}{*}{$\begin{array}{l}\text { Age } \\
\text { and } \\
\text { sex }\end{array}$} & \multicolumn{4}{|c|}{ Pressure in $\mathrm{mm} . \mathrm{Hg}$} & \multirow{2}{*}{\multicolumn{2}{|c|}{$\begin{array}{c}\text { Arterial } \mathrm{O}_{2} \\
\text { saturation } \\
\text { per cent }\end{array}$}} & \multirow{2}{*}{\multicolumn{2}{|c|}{$\begin{array}{l}\text { Pulmonary } \\
\text { blood flow in } \\
\text { 1./min. }\end{array}$}} & \multirow{2}{*}{\multicolumn{2}{|c|}{$\begin{array}{l}\text { Right-to-left } \\
\text { shunt as per- } \\
\text { centage of } \\
\text { systemic flow }\end{array}$}} & \multirow{3}{*}{$\begin{array}{l}\text { Clinical } \\
\text { result }\end{array}$} \\
\hline & & \multicolumn{2}{|c|}{$\begin{array}{c}\text { Right } \\
\text { ventricle }\end{array}$} & \multicolumn{2}{|c|}{$\begin{array}{l}\text { Pulmonary } \\
\text { artery }\end{array}$} & & & & & & & \\
\hline & & Before & After & Before & After & Before & After & Before & After & Before & After & \\
\hline $\begin{array}{l}\text { V7 } \\
\text { V23 } \\
\text { V41 }\end{array}$ & $\begin{array}{l}26 \mathrm{~F} \\
11 \mathrm{~F} \\
11 \mathrm{M}\end{array}$ & $\begin{array}{l}85^{*} \\
45^{*} \\
56^{*}\end{array}$ & $\begin{array}{c}\overline{23 / 0} \\
20^{*} \\
(60 / 0)\end{array}$ & $\begin{array}{c}11^{*} \\
4^{*} \\
9^{*}\end{array}$ & $\begin{array}{c}\overline{12 / 4} \\
9 * \\
(14 / 5)\end{array}$ & $\begin{array}{l}69 \\
68 \\
85\end{array}$ & $\begin{array}{l}85 \\
92 \\
97\end{array}$ & $\begin{array}{l}1.4 \\
1.5 \\
-\end{array}$ & $\begin{array}{l}3 \cdot 5 \\
3 \cdot 0 \\
4 \cdot 8\end{array}$ & $\begin{array}{l}53 \\
54 \\
-\end{array}$ & $\begin{array}{r}23 \\
0 \\
0\end{array}$ & $\begin{array}{l}\text { V. good } \\
\text { V. good } \\
\text { V. good }\end{array}$ \\
\hline $\begin{array}{l}\text { V47 } \\
\text { V59† } \\
\text { V73 } \\
\text { V78 } \\
\text { V94 } \\
\text { V95 }\end{array}$ & $\begin{array}{r}7 \mathrm{~F} \\
20 \mathrm{M} \\
19 \mathrm{~F} \\
7 \mathrm{~F} \\
3 \mathrm{M} \\
33 \mathrm{~F}\end{array}$ & $\begin{array}{l}180 / 8 \\
240 / 12 \\
144 / 5 \\
46^{*} \\
115 / 35 \\
110 / 5\end{array}$ & $\begin{array}{l}58 / 6 \\
48 / 10 \\
65 / 3 \\
31 / 0 \\
46 / 2\end{array}$ & $\begin{array}{c}20 / 7 \\
10^{*} \\
13 / 8 \\
19^{*} \\
16 / 8 \\
9 / 3\end{array}$ & $\begin{array}{c}28 / 11 \\
15^{*} \\
21 / 9 \\
19 / 6 \\
\overline{15 / 7}\end{array}$ & $\begin{array}{l}84 \\
60 \\
90 \\
89 \\
68 \\
90\end{array}$ & $\begin{array}{l}96 \\
89 \\
96 \\
98 \\
99 \\
94\end{array}$ & $\begin{array}{c}2 \cdot 7 \\
1 \cdot 1 \\
2 \cdot 0 \\
2 \cdot 7 \\
0 \cdot 8 \\
(7 \cdot 8)\end{array}$ & $\begin{array}{l}4 \cdot 7 \\
2 \cdot 0 \\
5 \cdot 6 \\
5 \cdot 3 \\
\overline{5 \cdot 0}\end{array}$ & $\begin{array}{l}30 \\
62 \\
17 \\
23 \\
50 \\
24\end{array}$ & $\begin{array}{r}0 \\
35 \\
0 \\
0 \\
0 \\
0\end{array}$ & $\begin{array}{l}\text { V. good } \\
\text { V. good } \\
\text { Good } \\
\text { Good } \\
\text { V. good } \\
\text { Good }\end{array}$ \\
\hline
\end{tabular}

* Mean pressures. $\quad$ † Case 7 of Soulié et al. (1952).

$\ddagger$ R.A. pressure had fallen from $15 / 5$ to $7 / 5$.

systemic arterial blood rose from 78 to 94 per cent; and the right-to-left shunt, expressed as a percentage of the systemic flow, fell from 37 to 5 per cent. Partly because of this and partly because of the reduced resistance at the pulmonary valve, the pulmonary flow increased from $2 \cdot 5$ to $4 \cdot 2$ litres a minute.

The 15 acyanotic patients showed very similar results. The average right ventricular pressure fell from $135 / 2$ to $62 / 1 \mathrm{~mm}$. with a pressure gradient of $44.5 \mathrm{~mm}$. and, as before, there was only a small increase in the pulmonary arterial pressure from $14 / 7$ to $17 \cdot 5 / 7 \mathrm{~mm}$. (Table VIII). None showed a normal right ventricular systolic pressure but in most patients it was between 40 and $65 \mathrm{~mm}$. There was, of course, no right-to-left shunt to be abolished and the arterial $\mathrm{O}_{2}$ saturation was not much changed $(97 \cdot 5$ instead of $96 \%)$. The increase in the pulmonary flow was less than in the cyanotic cases (average $5 \cdot 2$ instead of 4.6 litres a minute).

In both groups the right ventricular pressure is generally between one-half and one-third of what it was before operation. It is disappointing that it does not fall to normal and that there is still some degree of pulmonary stenosis. This is, however, slight instead of severe and gives rise to few, if any, symptoms and does not seem likely to do so. Possibly, the valve itself has been divided as much as is possible and the presence of the stenosis has led to some underdevelopment of the area round it and of the outflow tract of the right ventricle. It does not seem desirable that the surgeon should make greater efforts to split the pulmonary valve by the closed method as this would probably increase the risk of pulmonary regurgitation, which is a serious though uncommon complication that every effort should be made to avoid.

Perhaps the pressure gradient is the most satisfactory way of expressing the result. In three cases it was below $14 \mathrm{~mm}$. after operation; in ten it was between 25 and $39 \mathrm{~mm}$.; in five it was between 40 and $49 \mathrm{~mm}$. All these had good results except one with a pressure gradient of $45 \mathrm{~mm}$. (Case V80). In four it was still higher, above $50 \mathrm{~mm}$. In the first two of these, both excellent clinical results, it was 60 instead of 130 before operation (Case V43) and 78 instead of 158 (Case V30) and in both the right ventricular strain was reduced (Fig. 7). The third (Case V45) was improved, her heart became smaller, the right ventricular strain less, and the pressure gradient fell from 88 (mean) to 21 (mean) but the systolic pressure still showed a gradient of $94 \mathrm{~mm}$. These three were all early cases. The fourth (Case V108) was one of the failures although the gradient was reduced from 173 
TABLE VIII

Physiological Data in Acyanotic Pulmonary Valve Stenosis before and after Valvotomy

\begin{tabular}{|c|c|c|c|c|c|c|c|c|c|c|}
\hline \multirow{3}{*}{$\begin{array}{l}\text { Case } \\
\text { No. }\end{array}$} & \multirow{3}{*}{$\begin{array}{l}\text { Age } \\
\text { and } \\
\text { sex }\end{array}$} & \multicolumn{4}{|c|}{ Pressure in $\mathrm{mm} . \mathrm{Hg}$} & \multirow{2}{*}{\multicolumn{2}{|c|}{$\begin{array}{c}\text { Arterial } \mathrm{O}_{2} \\
\text { saturation } \\
\text { percentage }\end{array}$}} & \multirow{2}{*}{\multicolumn{2}{|c|}{$\begin{array}{l}\text { Pulmonary } \\
\text { blood flow in } \\
\text { l./min. }\end{array}$}} & \multirow{3}{*}{ Result } \\
\hline & & \multicolumn{2}{|c|}{ Right ventricle } & \multicolumn{2}{|c|}{ Pulmonary artery } & & & & & \\
\hline & & Before & After & Before & After & Before & After & Before & After & \\
\hline $\begin{array}{l}\text { V30 } \\
\text { V43 }\end{array}$ & $\begin{array}{l}12 \mathrm{M} \\
18 \mathrm{M}\end{array}$ & $\begin{array}{l}180 / 5 \\
150 / 8\end{array}$ & $\begin{array}{l}102 / 9 \\
80 / 2\end{array}$ & $22 / 10$ & $\begin{array}{l}24 / 7 \\
20 / 7\end{array}$ & $\begin{array}{l}97 \\
98\end{array}$ & $\begin{array}{l}99 \\
97\end{array}$ & $\begin{array}{l}4.0 \\
5.0\end{array}$ & $\begin{array}{l}3.9 \\
3.9\end{array}$ & $\begin{array}{l}\text { Good } \\
\text { Good }\end{array}$ \\
\hline V45 & $29 \mathrm{~F}$ & $\left\{\begin{array}{l}98^{*} \\
-\end{array}\right.$ & $\begin{array}{r}30^{*} \\
110 / 6\end{array}$ & $10^{*}$ & $\left.\begin{array}{r}9 * \\
18 / 5\end{array}\right\}$ & 93 & 98 & $3 \cdot 3$ & $3 \cdot 8$ & Good \\
\hline $\begin{array}{l}\text { V56 } \\
\text { V64 } \\
\text { V70 } \\
\text { V80 } \\
\text { V83 } \\
\text { V88 } \\
\text { V89 } \\
\text { V92 } \\
\text { V100 } \\
\text { V108 } \\
\text { V118 } \\
\text { V116 } \\
\text { V121 }\end{array}$ & $\begin{array}{l}23 \mathrm{M} \\
19 \mathrm{~F} \\
13 \mathrm{M} \\
25 \mathrm{~F} \\
19 \mathrm{~F} \\
11 \mathrm{M} \\
12 \mathrm{~F} \\
25 \mathrm{M} \\
12 \mathrm{M} \\
33 \mathrm{M} \\
20 \mathrm{~F} \\
21 \mathrm{M} \\
10 \mathrm{~F}\end{array}$ & $\begin{array}{l}114 / 0 \\
160 / 0 \\
140 / 5 \\
112 /-4 \\
124 / 2 \\
150 / 0 \\
105 / 4 \\
110 / 0 \\
100 / 2 \\
190 / 12 \\
121 / 0 \\
170 /-3 \\
130 / 4\end{array}$ & $\begin{array}{l}65 / 5 \\
53 /-4 \\
65 / 2 \\
55 / 0 \\
46 /-3 \\
50 /-2 \\
46 / 3 \\
55 /-2 \\
50 / 0 \\
107 / 5 \\
39 / 1 \\
62 / 0\end{array}$ & $\begin{array}{c}16 / 4 \\
1 \overline{16 / 10} \\
3 / 1 \\
10 / 6 \\
\overline{15 / 8} \\
10 / 4 \\
15 / 7 \\
\overline{18 / 9} \\
15 / 3 \\
25 / 14\end{array}$ & $\begin{array}{l}16 / 7 \\
15 / 4 \\
18 / 8 \\
10 /-4 \\
14 / 4 \\
16 / 7 \\
15 / 11 \\
16 / 5 \\
22 / 10 \\
17 / 10 \\
25 / 7 \\
12 / 3\end{array}$ & $\begin{array}{l}99 \\
95 \\
99 \\
94 \\
97 \\
94 \\
97 \\
92 \\
98 \\
96 \\
99 \\
98 \\
99\end{array}$ & $\begin{array}{l}98 \\
98 \\
97 \\
94 \\
96 \\
94 \\
99 \\
98 \\
98 \\
99 \\
99 \\
99\end{array}$ & $\begin{array}{c}5.4 \\
3 \cdot 8 \\
3 \cdot 7 \\
4 \cdot 6 \\
5 \cdot 2 \\
4 \cdot 8 \\
4 \cdot 6 \\
(6 \cdot 0) \\
5 \cdot 1 \\
3 \cdot 5 \\
(7 \cdot 9) \\
3.9 \\
3 \cdot 1\end{array}$ & $\begin{array}{l}4 \cdot 3 \\
5 \cdot 2 \\
6 \cdot 7 \\
5 \cdot 0 \\
5 \cdot 9 \\
5 \cdot 0 \\
6 \cdot 4 \\
7 \cdot 3 \\
5 \cdot 3 \\
4 \cdot 1 \\
3 \cdot 8 \\
3 \cdot 0\end{array}$ & $\begin{array}{l}\text { Good } \\
\text { Good } \\
\text { Good } \\
\text { Fair } \\
\text { Good } \\
\text { Good } \\
\text { V. good } \\
\text { Good } \\
\text { Good } \\
\text { Poor } \\
\text { Good } \\
\text { Good } \\
\text { Fair }\end{array}$ \\
\hline
\end{tabular}

to $90 \mathrm{~mm}$. Probably this failure should be attributed to the large degree of obstruction still remaining, and the third patient would also have been better if the stenosis had been relieved more completely.

\section{Pressure Changes at the Time of Operation}

Since October, 1951, the pressures in the right ventricle and pulmonary trunk have been recorded during operation, both before and after valvotomy, in as many patients as possible (Table IX). The results are difficult to interpret because the pressure has often fallen greatly from the effects of anæsthesia and operation and the state of the patient may have changed between the two readings and methedrine may have been injected. Generally, when figures before operation can be compared, the right ventricular systolic pressure had fallen to less than half, but sometimes it was better maintained, e.g. 120 compared with 150, and 97 compared with $112 \mathrm{~mm}$. Hg.

In many of the earlier cases the results looked disappointing even when the valvotomy seemed successful and where later there was no doubt about the clinical improvement. In Case V70 for example, the right ventricular pressure fell from 95 to $85 \mathrm{~mm}$. $\mathrm{Hg}$ only and yet catheterization a year after showed that it had fallen from 140 to $65 \mathrm{~mm}$. Even when the fall of pressure was not great, the pulse waves were often much better in the pulmonary tracings. There were, however, other readings that measured the improvement better; in Case V73, for example, the systolic pressure fell from 73 to 48 in the right ventricle and rose from 6 to $15 \mathrm{~mm}$. in the pulmonary trunk.

More recently, probably because of technical improvements in the recording for there is no evidence that the clinical results have become better, the pressure gradient across the stenosis has been greatly reduced more often. In ten consecutive cases, the average figures were $80 / 5$ and $16 / 8$ before operation and $48 / 3$ and $19 / 8 \mathrm{~mm}$. afterwards-a considerable fall in the pressure gradient-but even recently the records during operation have not always recorded the improvement that followed (Cases V116 and V121).

Few records show much rise in pulmonary pressure, but in a few it rose to about $30 \mathrm{~mm}$. In 
TABLE IX

Pressure Findings Before and After Valvotomy

\begin{tabular}{|c|c|c|c|c|c|c|c|c|}
\hline \multirow{3}{*}{$\begin{array}{l}\text { Case } \\
\text { No. }\end{array}$} & \multirow{2}{*}{\multicolumn{2}{|c|}{$\begin{array}{l}\text { Catheterization } \\
\text { before operation }\end{array}$}} & \multicolumn{4}{|c|}{ During operation } & \multirow{2}{*}{\multicolumn{2}{|c|}{$\begin{array}{l}\text { Catheterization } \\
\text { after operation }\end{array}$}} \\
\hline & & & \multicolumn{2}{|c|}{ Before valvotomy } & \multicolumn{2}{|c|}{ After valvotomy } & & \\
\hline & R.V. & P.A. & R.V. & P.A. & R.V. & P.A. & R.V. & P.A. \\
\hline V70 & $140 / 5$ & $16 / 10$ & $95 / 7$ & $18 / 11$ & $85 / 7$ & $18 / 10$ & $65 / 2$ & $18 / 8$ \\
\hline V73 & $144 / 5$ & $13 / 7$ & $73 / 0$ & $6 / 0$ & $48 / 0$ & $15 / 7$ & $63 / 3$ & $21 / 9$ \\
\hline V74 & & & $148 /$ & - & $70 / 0$ & $40 / 24$ & - & - \\
\hline V75 & $170 / 7$ & $10 / 7$ & $78 / 12$ & $13 /$ & $30 / 7$ & $21 / 13$ & - & - \\
\hline V76 & $155 / 0$ & $24 / 7$ & $60 / 5$ & $10 / 6$ & $47 / 5$ & $14 / 7$ & - & - \\
\hline V78 & $46 \mathrm{~m}$. & $17 \mathrm{~m}$. & $97 / 5$ & $14 / 6$ & $94 / \dot{y}$ & $16 / 10$ & $31 / 0$ & $19 / 6$ \\
\hline V79 & $90 / 4$ & $16 / 9$ & $41 / 4$ & $15 / 9$ & $32 / 6$ & $15 / 11$ & & $13 / 0$ \\
\hline V80 & $112 /-4$ & $3 / 1$ & $38 / 2$ & $5 / 1$ & $21 / 5$ & $11 / 7$ & $55 / 0$ & $10 / 2$ \\
\hline V83 & $120 / 2$ & $10 / 6$ & $60 / 5$ & $12 / 7$ & $60 / 10$ & $15 /$ & $46 /-3$ & $14 / 4$ \\
\hline V87 & $148 / 3$ & $15 / 6$ & $67 / 7$ & $14 / 9$ & $77 / 7$ & $19 / 12$ & 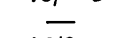 & \\
\hline V88 & $105 / 4$ & $14 / 8$ & $60 / 8$ & $24 / 12$ & $44 / 6$ & $36 / 10$ & $46 / 3$ & $15 / 11$ \\
\hline V90 & $140 / 5$ & $15 / 6$ & $30 / 4$ & $12 / 6$ & $36 / 4$ & $14 / 6$ & & 101.1 \\
\hline V92 & $110 / 0$ & $10 / 4$ & $55 / 3$ & $12 / 8$ & $45 / 0$ & $15 / 8$ & $55 / 2$ & $16 / 5$ \\
\hline V93 & $165 / 3$ & - & $80 / 2$ & $10 / 2$ & $35 / 3$ & $15 / 4$ & - & - \\
\hline V94 & $115 / 35$ & - & $55 / 15$ & $8 / 6$ & $50 / 7$ & $30 / 15$ & - & - \\
\hline V95 & $110 / 5$ & $9 / 3$ & $55 / 0$ & $5 / 1$ & $45 / 0$ & $10 / 3$ & $46 / 2$ & $15 / 7$ \\
\hline V97 & $160 / 10$ & $36 / 15$ & $110 / 0$ & $25 / 9$ & $53 / 0$ & $21 / 13$ & - & - \\
\hline V98 & $238 / 12$ & $22 / 10$ & $85 / 10$ & $26 / 21$ & $72 / 5$ & $25 / 15$ & - & - \\
\hline V100 & $120 / 0$ & $15 / 7$ & $89 / 0$ & $23 / 7$ & $55 / 0$ & $16 / 2$ & $51 / 0$ & $22 / 10$ \\
\hline V101 & $146 / 5$ & $22 / 7$ & $44 / 6$ & $18 / 11$ & $29 / 9$ & $24 / 14$ & & - \\
\hline V104 & $112 /-5$ & $25 / 10$ & $97 / 0$ & & $55 / 0$ & $20 / 3$ & - & - \\
\hline V105 & $150 / 0$ & $15 / 3$ & $120 / 10$ & $13 / 9$ & $72 / 10$ & $21 / 14$ & - & - \\
\hline V107 & & & $63 / 5$ & $6 / 4$ & $15 / 0$ & $7 / 1$ & - & - \\
\hline V108 & $190 / 10$ & - & $80 / 8$ & $5 / 3$ & $54 / 8$ & $16 / 11$ & $107 / 5$ & $17 / 10$ \\
\hline V114 & $139 / 5$ & $15 / 5$ & $100 / 25$ & $11 \mathrm{~m}$ & $43 / 15$ & $25 / 6$ & - & - \\
\hline V116 & $170 /-3$ & $15 / 3$ & $110 / 2$ & $14 / 1$ & $110 / 5$ & $25 / 2$ & - & - \\
\hline V118 & $121 / 0$ & $18 / 9$ & $73 / 0$ & $11 / 4$ & $35 / 0$ & $20 / 6$ & $39 / 1$ & $25 / 7$ \\
\hline V120 & $157 / 2$ & $12 / 3$ & $150 / 2$ & $22 / 8$ & $104 / 10$ & $20 / 10$ & 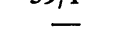 & \\
\hline V121 & $130 / 4$ & $25 / 4$ & $70 / 1$ & $26 / 13$ & $74 / 0$ & $35 / 18$ & $62 / 0$ & $12 / 3$ \\
\hline
\end{tabular}

Case V88 it rose to $36 / 10$ from $24 / 12$ before valvotomy. Catheterization some months after operation, however, showed that while the operative and post-operative records of the right ventricular pressure are the same, $44 / 6$ and $46 / 3$, the pressure in the pulmonary trunk has fallen from the figure of $36 / 10$ obtained at operation to $15 / 11$, which is almost identical with her pressure at catheterization before operation, when it was $14 / 8$ with a right ventricular pressure of $105 / 4 \mathrm{~mm}$. Although these pressure measurements during operation help to tell if the valvotomy has been carried out completely enough, they can not be taken as good evidence of how much the right ventricular pressure has been reduced permanently.

\section{Pulmonary Stenosis and a Patent Ductus Arteriosus}

Not many cases of pulmonary stenosis with a closed ventricular septum and patent ductus arteriosus have been reported, and the following patient is, therefore, of interest because she got on well till she was 36 and has been successfully cured of both her lesions. She is also an epitome of three stages in the treatment of congenital heart disease, the avoidance of all activity, a life of reasonable activity, and modern surgical treatment.

Mrs. W. T. (Case V97), aged 29, was first seen in 1946. Heart disease had been diagnosed when she was 18 months old and the doctor never allowed her to go to school because of this. When she was 15 , a new 
doctor told her to do more and she began to lead an active life, only a little more breathless than her friends, and was able to work in hospital as an assistant nurse during the war. Later she married and could lead a normal quiet life.

She had always had high coloured cheeks with some peripheral cyanosis with cold weather. The heart was very large (c.t.r. $66 \%$ ), and on screening this seemed to be mainly the right ventricle: the pulsation was less than usual for a large ductus. There was a characteristic continuous murmur and thrill in the upper half of the left chest and the blood pressure was 145/65. The cardiogram showed right ventricular preponderance and a large $R(14 \mathrm{~mm}$.) in V1 with no $S$ wave: $T$ was inverted in leads III and V1 to V3. This and the peripheral cyanosis indicated something as well as a ductus, and Dr. Terence East thought that she had pulmonary stenosis, and that there was an independent systolic murmur rather lower down. She was anxious to have a child but was advised against this, and adopted a baby the following year.

Five years later she was admitted for investigations. She could do all her ordinary housework and could walk 5 miles. The physical signs were unchanged. The arterial blood was fully saturated and the oxygen saturation rose from 59 in the right ventricle to 85 per cent in the pulmonary artery. The pressure in the right ventricle was very high, 158/10, and that in the pulmonary artery was only $36 / 16 \mathrm{~mm}$. The systolic pressure in the brachial artery was 134 at the same time, further evidence of a closed ventricular septum. The flow through the ductus was about two-thirds of the output of the left ventricle. The diagnosis of a patent ductus arteriosus and pulmonary stenosis was confirmed.

Though both these lesions could be cured by surgery, it seemed that with her age and her large heart the risk would be considerable, and as she had kept well without any further increase in heart size during these five years it was thought reasonable to delay a decision.

She was seen again two years later, when she was 36 , and had been losing ground progressively for a year. The heart had become still larger with a c.t.r. of 69 per cent (Fig. 10) and the T waves were now inverted in V4. Now she had started losing ground it seemed likely to continue and that unless she had an operation soon it would never be possible.

Pulmonary valvotomy and closure of the ductus were, therefore, performed and were not specially difficult. Six months later she was enormously better. She was doing all her heavy housework without symptoms; she had walked five miles without fatigue and felt herself as well as she had when she was at work during the war. The heart had become much smaller (c.t.r. $59 \%$ ) than it had been at any time since she first came under observation. A year later, she had taken on work at a school as well as her

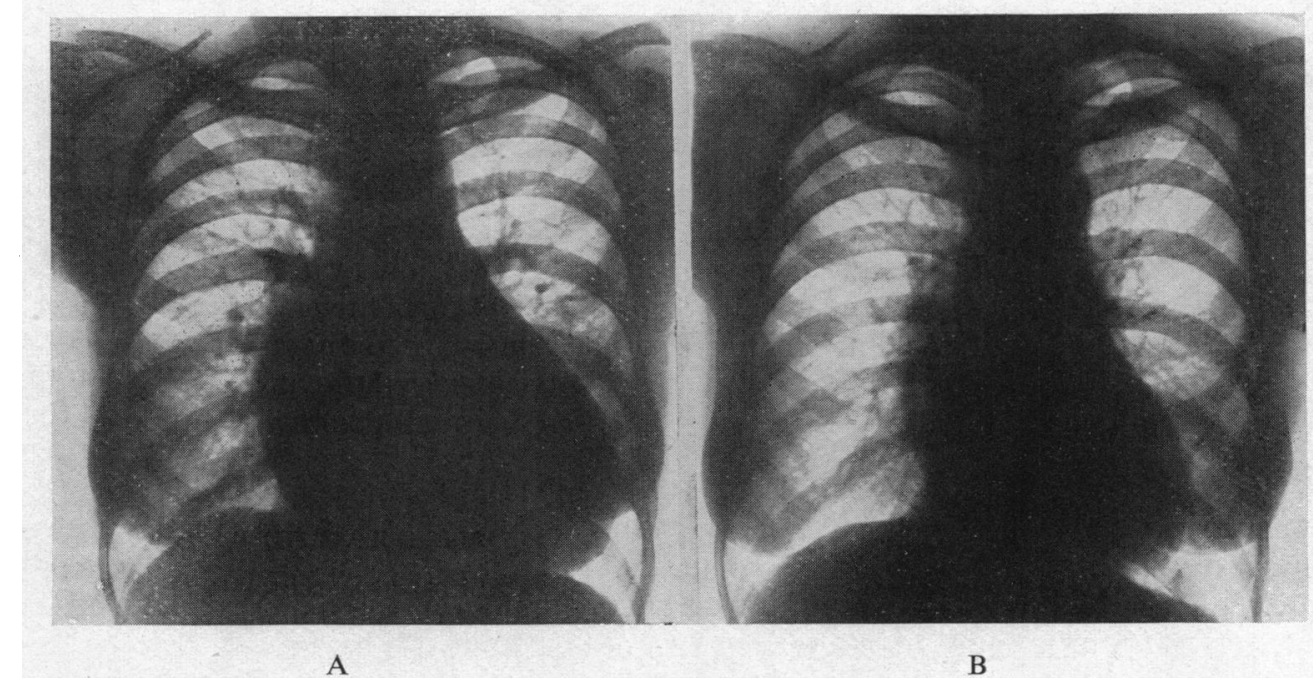

Fig. 10.-Enormous reduction in the size of the heart after operation in a patient of 35 who had simple pulmonary valvular stenosis and a patent ductuc arteriosus. (A) Before operation. The heart was very large (c.t.r. $69 \%: 17 \cdot 2 / 24 \cdot 8 \mathrm{~cm}$.) and had been nearly as large as this for at least 7 years and perhaps much longer. (B) One year after, showing a great reduction in the size of the heart (c.t.r. $55 \%$ : m.t.d. $13 \cdot 6 / 24 \cdot 8 \mathrm{~cm}$.) with corresponding clinical improvement. Case V97 (O532). 
household duties and was without any symptoms. She looks younger and her heart has decreased further (c.t.r. 55\%) (Fig. 10). Her cardiogram has improved and the $\mathrm{T}$ waves are now upright in $\mathrm{V} 4$ and less inverted in V2 and V3.

\section{Discussion}

Many patients with simple pulmonary stenosis do not need operation and get on well for years. It is, however, not always easy to judge when it is becoming serious for there may be severe stenosis with few symptoms.

In an attempt to find which features are most helpful in judging the prognosis and the need for operation, we have compared four findings in a large group of cases-moderately severe or progressive symptoms, a large heart with a cardiothoracic ratio of 54 per cent or above, the pattern of $\mathrm{T}$ inversion across the chest leads, generally to $\mathrm{V} 4$, and a systolic right ventricular pressure of over $100 \mathrm{~mm}$. Hg. Nearly half the severe cases that have been investigated show all these features so do not help to decide their relative significance. The only other group of any size consists of cases with all these features except the large heart, which shows that this is one of the later and more serious signs. There are also several cases with right ventricular pressure of over $100 \mathrm{~mm}$. but with little in the way of symptoms. It seems clear that by the time the symptoms are severe or the heart much enlarged, the best time for operation has passed, though the results can still be excellent.

Kirklin et al. (1953) and Blount et al. (1954) have suggested that a right ventricular pressure over $75 \mathrm{~mm}$. is an indication for operation regardless of symptoms. This may be so but we think it wiser not to accept this until more patients have been followed for a longer period after catheterization. Empirically, we have used a level of $100 \mathrm{~mm}$. $\mathrm{Hg}$.

Although catheterization should be widely used at present to establish more certain standards, we think that the electrocardiogram is of great value and provides the most decisive criterion. The patient without right ventricular preponderance has trivial stenosis and is unlikely to need operation at any time, but the patient with right ventricular preponderance should be watched for the development of strain. The pattern with deep T inversion in V3 (and still more if this spreads further to the right, as it often does even in patients with few symptoms) is probably the best indication for operation, as was suggested by Marquis (1951). Many of the patients dealt with here have, however, reached a much later stage and should in the future be operated on earlier.

Since Brock and Campbell (1950) first reported the results of valvotomy in simple pulmonary stenosis, many papers have been written confirming the good results obtained, but most of the series are small and have not yet been followed for long. Galligan et al. (1952) reported operation on 11 patients, all acyanotic, of whom one died. Kirklin et al. (1953) reported the results in 12 patients, of whom two died: they found that although the right ventricular pressure fell quickly it might not reach a normal level for some months, and thought that sometimes there was infundibular obstruction due to hypertrophy of the right ventricular muscle-a state of affairs that has sometimes been very evident post mortem. Therkelson (1953) reported operations on 12 patients, one of whom died and one of whom had a patent ductus also, but thought the follow-up period too short for valid conclusions. Humphreys et al. (1954) reported the results in 9 patients, most of whom were improved.

Dodrill et al. (1953) in describing a single operation under direct vision say that as time passes the pressure in the right ventricle may rise again, but their only reference for this is a personal communication of Lurie and Shumacker. In the discussion that followed their paper Lam stated that post-operative catheterizations had shown good results in all his twelve uncomplicated cases, but Schumacker said that his results had been disappointing in that there is only a slight fall in 5 patients and a large fall in 2, without a return to normal level in any. No doubt those with only a small fall would have been better with a more adequate operation and Humphreys pointed out that poor results might be due to this as he had found measuring the pressures at operation that his first attempt had not always been entirely effective. 
A larger and more detailed series of 33 cases was reported by Soulié and Vernant (1954): only two died and most of the others obtained good results clinically without much change in the physical signs. Generally, the heart did not become much smaller and the cardiogram did not change much, though they publish one record where deep T inversion from V1 to V5 was replaced by small upright, but still late-rising, $\mathrm{T}$ waves. These are the views expressed by Heim de Balsac and Escalle (1954) also and by Durand and Metianu (1954). Soulié et al. (1952) had already reported the results of catheterization one to nine months after operation in 9 of these cases. The average fall in the right ventricular systolic pressure was from 160 to $108 \mathrm{~mm}$. $\mathrm{Hg}$-rather less than in our cases. They found the fall was small in 5, moderate in 2, and large in 2 cases. The pressure in the pulmonary artery rose " mais cette augmentation reste toujours très modérée et sans rapport avec le degré de la chute de pression ventriculaire droite" (Soulié and Vernant, 1954).

Dubost and D'Allaines (1954) have used the pulmonary arterial route and discuss this in detail: there were 4 deaths among 25 cases and the late results were said to be comparable with those achieved by the transventricular method. Sondergaard (1953) has also used this method in three cases.

Hosier, Pitts, and Taussig (1954) report the results in 86 patients, 7 of whom died: 4 of these had had a subclavian-pulmonary anastomosis previously, and these accounted for 2 of the deaths. Sixty-nine patients had been followed for up to 4 years, and most of them were improved. Nearly half showed a decrease in heart size and more than half showed some reduction in right ventricular strain. Catheterization had been carried out in 17 before and after operation. But these comments are taken from a short summary only and the full paper has not been seen. It sounds, however, as if their results are very similar to those we have described.

Blount et al. (1954) have described the results in 15 patients operated on in the usual way up to 1953 and 5 patients operated on since through a pulmonary arterial approach under hypothermia. Five patients of each group had catheterization repeated after operation. In the former the average right ventricular systolic pressure fell from 168 to $65 \mathrm{~mm}$., with a small rise in the pulmonary arterial pressure from $16 / 10$ to $22 / 10 \mathrm{~mm}$.- figures that are very similar to ours in both respects. In the latter group who had open operations under hypothermia, the average pressure fell from 116 to a normal figure of $28 \mathrm{~mm}$. and the pulmonary arterial pressure rose from 19/10 to $23 / 7 \mathrm{~mm}$.

At first sight these results seem even better, but although none of their five patients died, operations under hypothermia can not yet be regarded as equally safe, and further there was a high incidence of pulmonary regurgitation, which they dismiss lightly. In the first group only one patient is stated to have developed a pulmonary diastolic murmur, but in the second group who had open operation at least four or perhaps all five patients did so. It is not clear how frequently the heart became larger, but this seems to have been common and they state: " The increase in heart size was more pronounced in the patients treated by wide excision of the pulmonic valve, and the murmur of pulmonic insufficiency was of greater intensity in these patients." In general, slight stenosis of the aortic or pulmonary valve is less serious than slight incompetence: their theoretical arguments that pulmonary incompetence is not so important remain to be proved and it can be a serious lesion. This production of significant regurgitation may, however, be the result of doing too much to the valve and may be avoided in future.

The case for transarterial valvotomy under hypothermia is as yet unproven and must await a larger series in which the mortality and results can be compared with the larger number done by the transventricular route. It is, for instance, uncertain that the pressure gradient can be corrected completely when the valve is thick, fibrous, and rigid. Although none of their five patients died, operations under hypothermia can not yet be regarded as equally safe, and most of the deaths in our series were in severely ill patients with a large heart in whom ventricular fibrillation developed early in the operation: these are just the type of case in which hypothermia is likely to prove dangerous. If operation needs to be repeated because it has been unsuccessful, the transarterial route would seem preferable. 
SUMMARY

Pulmonary valvotomy is a safe and successful treatment for simple pulmonary stenosis with a closed ventricular septum, when this is severe enough to need it. 'The 58 patients treated at Guy's Hospital have been followed and reported fully and 34 others gave similar results, making 92 in all.

In cyanotic cases the shunt can always be lessened and generally abolished. The average arterial $\mathrm{O}_{2}$ saturation in our cases rose from 78 to 94 per cent and with this the polycythæmia disappeared: the pulmonary flow was increased from 2.5 to 4.2 litres a minute. In other particulars the cyanotic and acyanotic cases can be considered together.

Omitting the early very severe cases there have been only three deaths among 52 consecutive cases-less than 6 per cent. The clinical results are good in 46 of the 50 who survived operation and disappointing in 4 patients only.

This clinical impression is supported by improvement in physical findings. When the heart is enlarged it generally becomes smaller: the average decrease was nearly 10 per cent, the cardiothoracic ratio falling from 60 to 54 per cent. When there is electrocardiographic evidence of right ventricular strain this often becomes less and sometimes disappears entirely, and the signs of right ventricular preponderance become less. Reversal of the pattern of right ventricular strain can not be promised always, especially if it has been present for a long time or if the heart is large.

Valvotomy for simple pulmonary stenosis is, therefore, a more satisfactory operation than either direct or anastomotic operations for Fallot's tetralogy for it more nearly achieves the ideal of restoring the heart to normal. It does not quite achieve this but converts the pulmonary stenosis from a severe to a slighter degree that generally does not seem of great importance.

In the 24 cases that have had catheterization repeated since their operation, all have shown a great reduction of the right ventricular systolic pressure-never to less than one-half and generally to about one-third of what it was before. Two have shown a fall to a normal pressure. The increase in the pulmonary arterial pressure is much smaller but the pressure gradient is on the average reduced from 122 to $42 \mathrm{~mm}$.

None of these patients has shown any evidence of the stenosis becoming more severe again during the period of observation. Several have been followed for four years and one who was incapacitated before operation remains just as well and is leading an active life six years later.

We are greatly indebted to Dr. D. Deuchar for the earlier and Dr. R. Shephard for the later catheterization reults, and to the Registrars of the National Heart Hospital for those of Cases 23, 80, and 88. We should also like to thank Dr. Charles Baker for referring Cases 75, 93, and 104, Dr. James Brown for Case 86, Dr. Frances Gardner for Case 78, and Professor Soulie for Case 59, and to thank the two latter for the results of catheterization also.

A summary was presented to the Second World Congress of Cardiology at Washington in September, 1954.

\section{REFERENCES}

Blount, S. G. Jr., McCord, M. C., Mueller, H., and Swan, H. (1954). Circulation, 10, 161.

Brock, R. C., and Campbell, M. (1950). Brit. Heart J., 12377.

Campbell, M. (1954). Brit. Heart J., 16, 273.

- and Deuchar, D. C. (1953). Brit. Heart J., 1, 349.

- , and Brock, R. (1954). Brit. med. J., 11, 111.

de Balsac, R. H., and Escalle, J. E. (1954). In Traité des Cardiopathies Congénitales, Masson et cie, Paris.

- Metianu, C., Durand, M., and Dubost, Ch. (1954). Traité des Cardiopathies Congénitales. Paris.

Dodrill, F. D., Hill, E. Gerisch, R. A., and Johnson, A. (1953). J. thorac. Surg., $26,584$.

Dubost, C., and D'Allianes, C. (1954). J. Chir. (Paris), 70, 105.

Durand, M., and Metianu, C. (1954). In Traité des Cardiopathies Congénitales. Masson et cie, Paris.

Galligan, J. J., Adams, F. H., and Jorgens, J. (1952). J. Pediat., 41, 562.

Hosier, D. M., Pitts, J. L., and Taussig. H. B. (1954). Second World Congress of Cardiology: Abstracts of Papers, p. 382.

Humphreys, G. H., Powers, S., Fitzpatrick, H., and Lanman, B. M. (1954). Surgery, 35, 9.

Kirklin, J. W., Connolly, D. C., Ellis, F. H., Burchell, H. B., Edwards, J. E., and Wood, E. H. (1953). Circulation, 8, 849.

Marquis, R. M. (1951). Brit. Heart J., 13, 89.

Sondergaard, T. (1953). Acta chir. scand., 104, 362.

Soulié, P., Joly, F., Carlotti, J., Sicot, J. R., and Voci, G. (1952). Arch. Mal Coeur, $45,385$.

, and Vernant, P. (1954). La Semaine Hôp. Paris, 30, 607.

Therkelsen, F. (1953). Acta chir. scand., 104, 353. 